\title{
Balance Model to Calculate the Ventilation Rate of a Mechanically Ventilated Finishing Pig House in East China
}

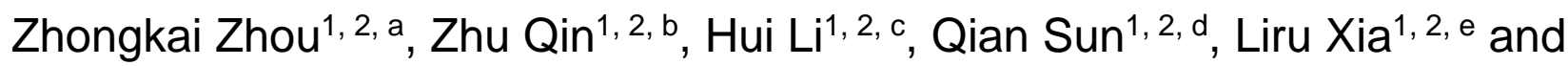 \\ Gang $\mathrm{Yu}^{1,2, \mathrm{f}}$ \\ ${ }^{1}$ Institute of Facilities and Equipment in Agriculture, Jiangsu Academy of Agricultural Science, \\ Nanjing 210014, China;
}

${ }^{2}$ Key Laboratory of Protected Agriculture Engineering in the Middle and Lower Reaches of Yangtze River, Ministry of Agriculture, Nanjing 210014, China

azhouzk@jaas.ac.cn, b99701723@qq.com, chuil@jaas.ac.cn, dwendysunnjau@sina.com, exIrjaas@126.com, fyug55@163.com.

Keywords: Pig production, Climate, Mechanical ventilation, Sensible heat, Moisture balance.

\begin{abstract}
This paper studies the ventilation rate of a mechanically ventilated finishing pig house with manure gutters from January $23^{\text {th }}$ to $26^{\text {th }}, 2016$. The barn is located at the suburbs of Huainan, a city at north of Jiangsu in eastern China. Two methods for the calculation of the ventilation rate in pig building were compared based on the balances of animal heat and moisture for growing pigs. Data of temperature, relative humidity and air velocity was obtained in the interior of building, as well as the external conditions. The operational status and rotational speed of ventilation fans were monitored at six stages. The analysis shows that temperature of all units in pig house ranged from $11.5^{\circ} \mathrm{C}$ to $14.7^{\circ} \mathrm{C}$ about $30 \mathrm{~min}$ in average, and relative humidity from $44.9 \%$ to $82.6 \%$. The average air temperature inside the pig house was $13.7^{\circ} \mathrm{C}$, while the relative humidity was $69.7 \%$. The inside air temperature was increased by $17.8^{\circ} \mathrm{C}$ and relative humidity reduced by $6.8 \%$ in average than outside. The average air velocity in the lower area of the building was $0.28 \mathrm{~m} / \mathrm{s}$. The average inlet and outlet air velocity of the pig building were 3.2 and $5.3 \mathrm{~m} \cdot \mathrm{s}^{-1}$, respectively. The directly measured ventilation rate of a pig barn was $6069 \mathrm{~m}^{3} \cdot \mathrm{h}^{-1}$. The average moisture and heat balance ventilation rate of pig barn was $6207 \mathrm{~m}^{3} \cdot \mathrm{h}^{-1}, 5880 \mathrm{~m}^{3} \cdot \mathrm{h}^{-1}$, and the difference of ventilation rate between directly measured and balance measured during the field experiment was $137 \mathrm{~m}^{3} \cdot \mathrm{h}^{-1}, 189 \mathrm{~m}^{3} \cdot \mathrm{h}^{-1}$ respectively.
\end{abstract}

\section{Introduction}

Air emissions from livestock production can be categorized broadly into GHG emissions and all other air-pollutant emissions, such as ammonia $\left(\mathrm{NH}_{3}\right)$, methane $\left(\mathrm{CH}_{4}\right)$, nitrous oxide $\left(\mathrm{N}_{2} \mathrm{O}\right)$, and carbon dioxide $\left(\mathrm{CO}_{2}\right)$ [1]. Livestock and their waste are major source of gaseous emissions, as well as affect soil and water quality. Ammonia is an atmospheric pollutant and responsible for eutrophication and soil acidification, while $\mathrm{CO}_{2}, \mathrm{CH}_{4}$ and $\mathrm{N}_{2} \mathrm{O}$ are greenhouse gases (GHG) that contribute to global warming [2]. Quantification of gaseous emissions requires determination of the concentration of the air contaminant and the ventilation rate of the emitting source. One key issue is to estimate the ventilation rate and then to quantify the gaseous emissions [3]. In confined swine house, ventilation is critical to ensure comfortable indoor environment for animal production. Several article proved that appropriate ventilation can also improve air quality inside pig buildings [4]. However, measuring ventilation rates in commercial animal houses is difficult in practice [5].

A number of primary techniques exist for determining ventilation rate of livestock buildings, including: anemometers, tracer gas, heat and moisture balance method. An approach applicator to mechanically ventilated buildings is to measure the air velocities of the exhaust fans under specific static pressure and monitoring of number of operating fans [6]. Hot wire and three dimensional ultrasonic wind anemometers can be used to measure the air velocity in a ventilation opening [7, 8]. A new technique, known as the Fan Assessment Numeration System (FANS), was introduced for continuously monitoring exhaust fan to improve in situ measurement accuracy of fan airflow capacity 
[9]. However, continuously monitoring or regularly checking airflow of ventilation fans can be a daunting task, especially in barns with numerous fans [10].

Tracer gas techniques have become widely used to measure the ventilation rates in buildings indirectly and showed reliable results. The basic principle of the method is the conservation of mass in the ventilation process: by monitoring the injection and concentration of the tracer, the exchange of air in the building can be determined [7]. The tracer gas method can be applied in three different ways, including: tracer gas decay, constant concentration and constant injection rate method. Tracer gases used in the literature including nitrous oxide $\left(\mathrm{N}_{2} \mathrm{O}\right)$ [11], carbon monoxide $(\mathrm{CO})$ [12], carbon dioxide $\left(\mathrm{CO}_{2}\right)$ [6], sculpture hexafluoride $\left(\mathrm{SF}_{6}\right)$ [13], and krypton $\left({ }^{85} \mathrm{Kr}\right)$ [14]. The $\mathrm{CO}_{2}$ mass balance method has been applied to determine the ventilation rate from both mechanically and from naturally ventilated [15] livestock buildings. However, applications of tracer gases in production facilities are often limited because the process requires uniform air - tracer mixing to ensure good results, which is difficult to achieve in commercial production settings. Van Buggenhout et al [16] demonstrated that in a mechanically ventilated test installation with accurate reference method, tracer gas experiments were performed to demonstrate the apparent difficulties. Certain tracer gases, such as $\mathrm{SF}_{6}$, also cause negative impacts to the environment.

Blames and Pedersen [17] described some steady-state balance methods for ventilation rate measurements of pig building, including heat balance and moisture balance. Then measurements of outdoor and indoor temperature and relative humidity were made, it was possible to calculate the ventilation rate based on the heat and moisture balances of the building [18]. These methods largely depend on the animal production of sensible heat and latent heat. Sameer [1-3] investigated factors that influence moisture and heat production include flooring system, stocking, density, watering, and moisture content of the forages, animal activity and relative humidity. Sensitivity analysis showed that the estimations were more precise in cold than in warm periods, and it was concluded that heat and moisture balances were not applicable for calculations of ventilation rate in uninsulated buildings [17]. The heat and moisture balance showed reliable results through winter seasons and acceptable results to some extent through summer seasons [1]. The objective of this paper was to compare moisture and sensible heat based balance methods for the estimation of ventilation rates in a mechanically ventilated pig house based on 30 min values with wall fan outlet and sidewall inlets.

\section{Materials and methods}

\subsection{Description of the pig building}

This study is based on measurements recorded at an experimental pig building located at the suburbs of Huainan, a city at north of Jiangsu in East China $\left(33^{\circ} 30^{\prime} 57.81^{\prime \prime} \mathrm{N}, 118^{\circ} 49^{\prime} 23.54 \mathrm{E}\right.$ ", $17 \mathrm{~m}$ amsl; coordinates refer to the building's location). Field experiments were carried out during the cold season. The mechanically ventilated pig barn with manure water flushing systems, as shown in Figure 1 , has dimensions of $54.0 \times 14 \times 3.6 \mathrm{~m}(\mathrm{~L} \times \mathrm{W} \times \mathrm{H})$ and a capacity of 500 pigs. The pig barn was divided to 2 sections $(54.0 \times 7.0 \mathrm{~m})$ arranged on the south-north orientation with partition wall. Every section approximately 250 animals were hosted in 7 pig pen. Each pen contained one feeder and one drinker and occupied by a total of 36 animals. New pigs were sent into the barns at about $20 \mathrm{~kg}$ and were marketed at about $110 \mathrm{~kg}$. The growth cycles were 4 to 5 months long.

The barn had air inlets on both north and south sidewalls. Each air inlet had dimensions of $55.0 \times$ $25.0 \mathrm{~cm}(\mathrm{~W} \times \mathrm{H})$, with $1.8 \mathrm{~m}$ height from the floor. There were three ventilation fans in the west wall of each sections of pig barn. One continuous $92-\mathrm{cm}$ diameter-belted variable speed fan was located in the center of the two fans. Two fans were $130-\mathrm{cm}$ diameter-belted exhaust fans. During colder weather, the sidewall air inlet was open, allowing uniform fresh air to enter the barns. Each barn had two hydronic methods to keep the barn warm when the indoor temperature was too low in cold weather. In warm weather, the barns were always under tunnel-ventilated conditions, and two 1.30-m exhaust fans normal operation. Manure storage was collected in gutters along the length of the barns from east to west, and flowed into outside storage cesspool. 


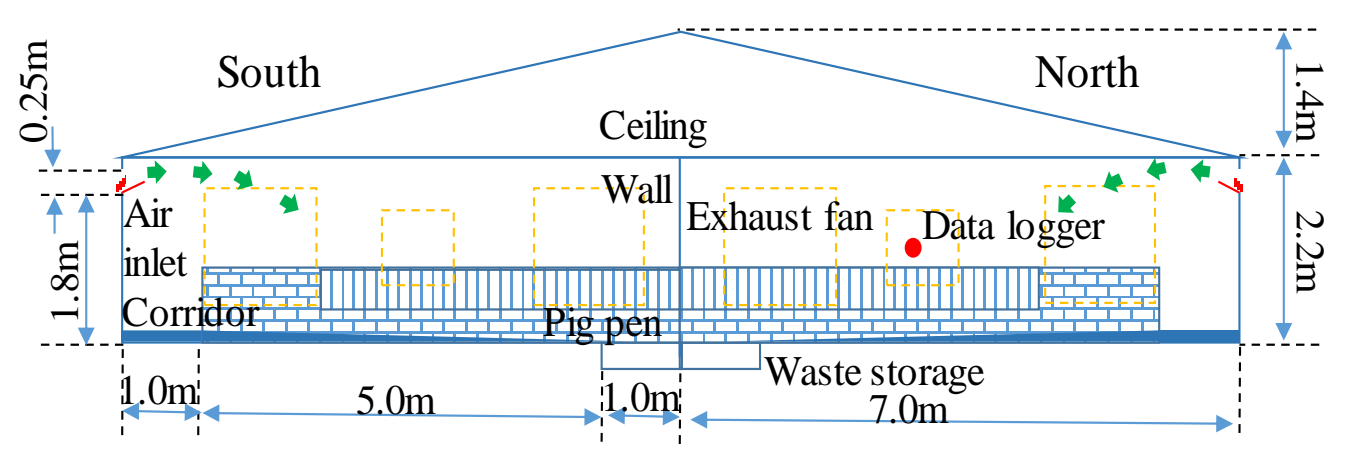

Fig. 1. Pig barn dimensions and positions of ventilation openings.

\subsection{Data acquisition procedures}

The field experiment was conducted as the first step to determine the main environmental problems in the commercial pig house during the cold season. Air temperature, humidity, ventilation rate, and wall surface temperature were measured during three days (January $23^{\text {th }}$ and $26^{\text {th }}, 2016$ ) with stable weather conditions to obtain reliable data.

To monitor the thermal environment, the three sensors were installed in the building at $1.0 \mathrm{~m}$ height, across the length of the building in the central axis distributed $13.5 \mathrm{~m}$ apart from each other. Outdoor air temperature and relative humidity were monitored with a sensor placed $10 \mathrm{~m}$ away from the barn, and protected in a plastic shield with lateral slots in order to be protected from water and indoor dust. The air temperatures and relative humidity inside and outside the pig building were measured using an HOBO Data Logger (HOBO U23-001, Corporation, Pocasset, MA, USA) with accuracy of $\pm 0.21^{\circ} \mathrm{C}$ and $\pm 2.5 \%$, respectively. A noncontact infrared thermometer (Fluke 572-2, Fluke, WA, USA) was used to measure the surface temperatures of each wall during the experimental period with the emissivity values of $0.95,0.8,0.85$ and 0.90 for concrete, iron materials, glass and pig, respectively.

The air velocities at each inlet and outlet were measured using digital anemometers (TM826, TECMAN, HK, China) and the averaged air velocity was used to calculate the ventilation rates. Exhaust fan capacity was monitored at the beginning and end of the experiment. Air velocity data was collected during day and night periods at three different points across the length of the building in the central axis at $1.0 \mathrm{~m}$ of height.

\subsection{Mathematical model}

The ventilation rate throughout the building can be determined by calculating the mass balance of $\mathrm{H}_{2} \mathrm{O}$ flow. The calculations of moisture balance were based on Blames, Pedersen and Schauberger [17, 18, and 19]. The following mathematical model describes the moisture balance:

$$
V_{\text {moist }}=\frac{3600 A L}{h_{\text {vap }}\left(H_{i}-H_{o}\right)}
$$

Where, $V_{\text {omits }}\left(\mathrm{m}^{3} \cdot \mathrm{h}^{-1}\right)$ represents the ventilation rate subject to the moisture balance, $\mathrm{L}(\mathrm{W})$ is the latent heat production [Eons (3)], $H_{i}(\%)$ is the relative humidity inside the building and $H_{o}(\%)$ is the relative humidity outside the building.

$h_{a p}\left(\mathrm{~J} \cdot \mathrm{kg}^{-1}\right)$ is the heat of vaporization of water, that can be obtained, according to the indoor temperature $T_{i}\left({ }^{\circ} \mathrm{C}\right)$ from the expression: $\left(2501-2.42 T_{i}\right) \times 10^{3}$. On the other hand, $A$ represents the relative animal activity according to the different animal actions during every 24 -h period, and can be calculated as follows equations [Eons (2)]:

$$
\mathrm{A}=1-\mathrm{a} \sin \left(\frac{2 \pi}{24}\left(h+6-h_{\min }\right)\right)-b \sin \left(\frac{2 \pi}{c}(h-d)\right)
$$

Where, his time of day ( 24 hour clock), and $h_{\min }=1, \mathrm{a}=0.31, \mathrm{~b}=0.15, \mathrm{c}=6.0$ and $\mathrm{d}=11.4$ are constants.

$$
\mathrm{L}=\Phi_{\text {tot }}^{*}-S
$$


Where, $\Phi^{*}{ }_{t o t}(\mathrm{~W})$ represents the total heat production at temperatures different from $20{ }^{\circ} \mathrm{C}$, and $\mathrm{S}$ (W) is the sensible heat production at house level, can be calculated as follows equations [Eqns (4) and (5)]:

$$
\Phi_{\text {tot }}^{*}=N\left[\Phi_{\text {tot }}+0.012 \Phi_{\text {tot }}\left(20-T_{i}\right)\right]
$$

Where, $\Phi_{t o t}(\mathrm{~W})$ represents the total heat production for fattening pigs at $20{ }^{\circ} \mathrm{C}$, and $\mathrm{N}$ represents the number of pigs housed in the building.

$$
\mathrm{S}=K_{S}\left(0.62 \Phi_{\text {tot }}^{*}-1.15 \times 10^{-7} T_{i}^{6}\right)
$$

Where, $K_{s}$ represent a correction factor for the sensible heat production at house level. $\Phi_{t o t}(\mathrm{~W})$ can be calculated as follows equations [Eons (6)], Where $m(\mathrm{~kg})$ represents the live mass.

$$
\Phi_{\text {tot }}=5.09 m^{0.75}+[1-(0.47+0.003 m)]\left[n \times 5.09 m^{0.75}-5.09 m^{0.75}\right]
$$

The heat balance equation for the sensible heat can be written as (Blames et al, 2005):

$$
V_{\text {heat }}=\frac{3600\left(A S-S_{\text {trans }}\right)}{h_{s p} \rho\left(T_{i}-T_{O}\right)}
$$

Where, $H_{\text {eat }}\left(\mathrm{m}^{3} \cdot \mathrm{h}^{-1}\right)$ is the ventilation flow from the sensible heat balance, $h_{\text {asp }}\left(\mathrm{J} \cdot \mathrm{kg}^{-1} \cdot{ }^{\circ} \mathrm{C}^{-1}\right)$ is the specific heat of air, $\rho\left(\mathrm{kg} \cdot \mathrm{m}^{-3}\right)$ is the air density, $T_{o}\left({ }^{\circ} \mathrm{C}\right)$ is the outdoor temperature of air, $S_{\text {trains }}(\mathrm{W})$ is the transfer of sensible heat through the building, can be calculated as follows equations [Eons (8)]:

$$
S_{\text {trans }}=\sum_{j}^{n} U_{j} A_{j}\left(T_{i}-T_{0}\right)
$$

Where, $U_{p}\left(\mathrm{~W} \cdot \mathrm{m}^{3} \cdot{ }^{\circ} \mathrm{C}^{-1}\right)$ is the thermal transmission coefficient, $A_{j a}\left(\mathrm{~m}^{2}\right)$ is the area of all these elements. Data values were analyzed statistically using the statistical package SAS 9.2 (SAS Institute Inc., Cary, NC, USA).

\section{Results}

\subsection{Climate conditions}

Descriptive statistics for environmental indicators in pig building are presented in Table 1 . The range of surface temperature for pig building was wide, with wall temperature ranging from 7.6 to $14^{\circ} \mathrm{C}$, then ceiling and floor temperature was $15.3,21.2^{\circ} \mathrm{C}$, respectively. The average air temperature inside the pig house was $13.7^{\circ} \mathrm{C}$, while the relative humidity was $69.7 \%$. On the other hand, the average outdoor air temperature was $-4.6^{\circ} \mathrm{C}$, and the average relative humidity was $65.2 \%$.

The inlet air was slightly warmed near the ceiling and moved downwards to both sides of the walls of the pens. Due to the minimum ventilation by the air fan attached to one side of the wall, the average air velocity in the lower area of the building was $0.28 \mathrm{~m} / \mathrm{s}$. The average inlet and outlet air velocity of the pig building were 3.2 and $5.3 \mathrm{~m} \cdot \mathrm{s}^{-1}$, respectively.

Table 1, Environmental indicators in pig building

\begin{tabular}{ccc}
\hline Class & Location & Value \\
\hline & Wall & East: 7.6 West: 14.0 \\
Surface temperature $/{ }^{\circ} \mathrm{C}$ & Ceiling & 15.3 \\
& Floor & 21.2 \\
& Indoor & 13.7 \\
Air temperature $/{ }^{\circ} \mathrm{C}$ & Outdoor & -4.6 \\
& Indoor & 0.00832 \\
Air humidity $/ \mathrm{kg} \cdot \mathrm{m}^{-3}$ & Outdoor & 0.00239 \\
Air velocity $/ \mathrm{m} \cdot \mathrm{s}^{-1}$ & & 0.28 \\
Inlet air velocity $\mathrm{m} \cdot \mathrm{s}^{-1}$ & & $3.2(2.5 \sim 3.8)$ \\
Outlet air velocity $/ \mathrm{m} \cdot \mathrm{s}^{-1}$ & $5.3(4.5 \sim 6.1)$ \\
\hline
\end{tabular}

Fig. 2a shows the air temperature inside and outside of the pig house in different measuring points during the field experiment between 00:00 and 23:00 when air temperatures of inside pig house were 
relatively stable without sudden drop due to door opening for internal managements. On the other hand, the outside temperature reached its maximum $1.3^{\circ} \mathrm{C}$ at $12: 30$ and then decreased to its minimum $-8.2{ }^{\circ} \mathrm{C}$ at $22: 30$. The analysis shows that indoor average half hour temperature across all units ranged from $11.5^{\circ} \mathrm{C}$ to $14.7^{\circ} \mathrm{C}$. The difference between indoor and outdoor temperature during the experiment ranged between $11.0^{\circ} \mathrm{C}$ and $21.7^{\circ} \mathrm{C}$, while its mean value equaled to $17.8^{\circ} \mathrm{C}$. It is clear that temperature levels during inside were higher than the outside $(\mathrm{P}<0.05)$.

Relative humidity levels inside and outside the pig building are presented in Fig. 2b, when data from three measuring points were available. During the field experiment relative humidity inside the pig house varied between $44.9 \%$ and $82.6 \%$, and the relative humidity outdoor varied between $41.6 \%$ and $80.3 \%$. The difference between indoor and outdoor relative humidity during the experiment ranged between $0 \%$ and $22.4 \%$, while its mean value equaled to $6.8 \%$. Significant differences were detected between indoor and outdoor relative humidity levels $(\mathrm{P}<0.05)$. Pedersen [17] investigated a useable prediction of the ventilation rate was possible on a $24 \mathrm{~h}$ basis when the inside to outside differences of air temperature and absolute humidity were larger than $2{ }^{\circ} \mathrm{C}, 0.5 \mathrm{~g} \cdot \mathrm{m}^{-3}$, respectively.

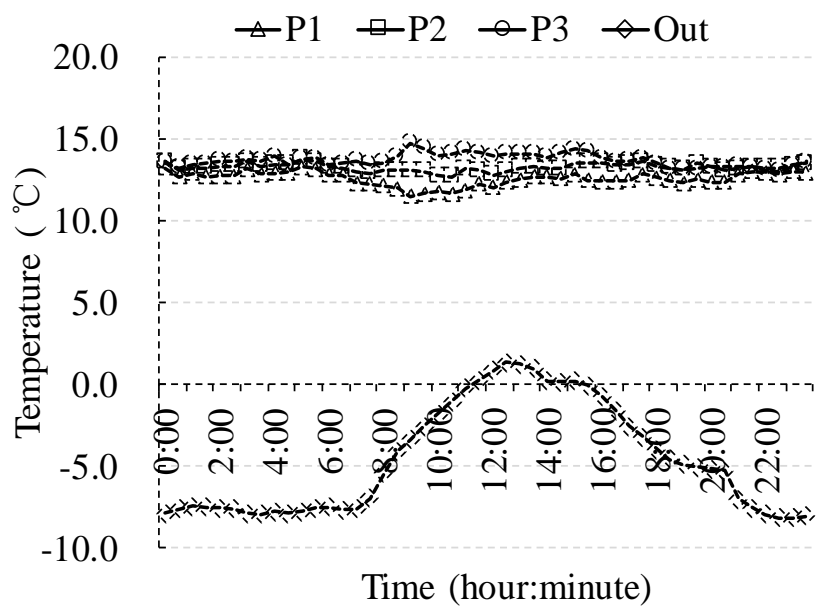

Fig. 2a Temperature

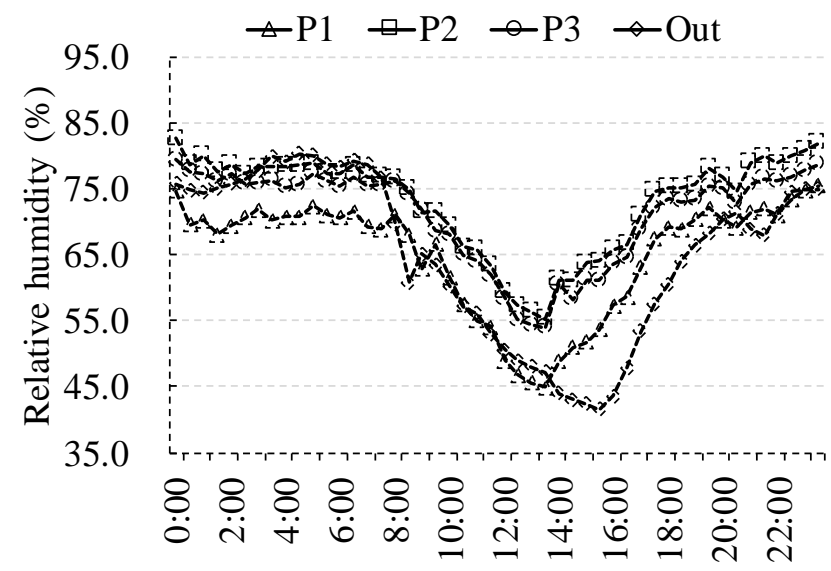

Time (hour:minute)

Fig. 2b Relative humidity

Fig. 2 Measured outdoor and indoor air temperatures and relative humidity

\subsection{Ventilation rate}

Ventilation rate are very important considerations in a pig house ventilation system. Three methods for the calculation of the ventilation rate in east China pig house with mechanical ventilation were compared on the basis of the balances of animal sensible heat, moisture balance and direct measurement. Fig. 3 shows the ventilation rate over $30 \mathrm{~m}$ minutes based on the three methods. Tables 2 show the average ventilation rate in pig house through six stage, according to the different measurement methods, which are: moisture balance, sensible heat balance and direct measurement.

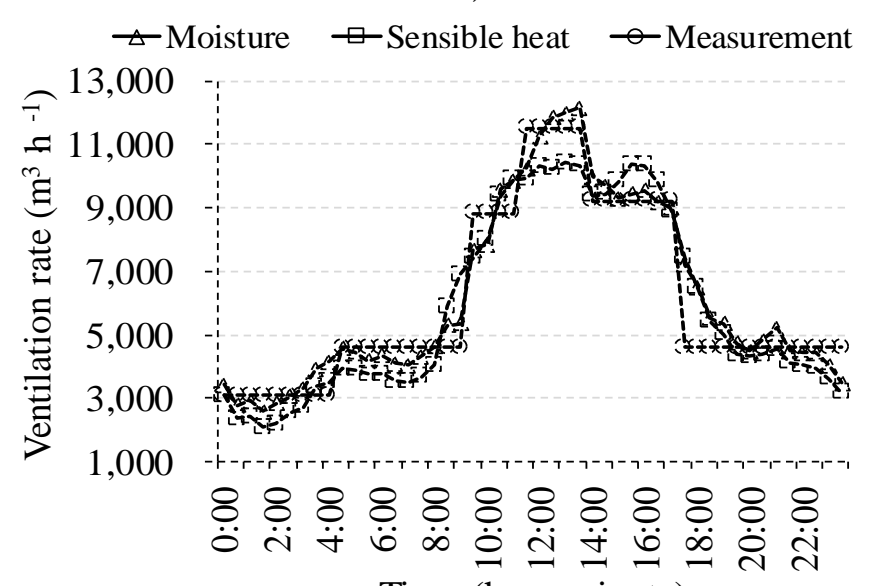

Time (hour:minute)

Fig. 3 Diurnal variation of ventilation rate for pig building based on sensible heat, moisture balance and direct measurement 
The three methods determined ventilation rates showed the same pattern in following the outside temperature profile. The directly measured ventilation rate of a pig barn ranged from $3100 \mathrm{~m}^{3} \cdot \mathrm{h}^{-1}$ to $11520 \mathrm{~m}^{3} \cdot \mathrm{h}^{-1}$ with an average of $6069 \mathrm{~m}^{3} \cdot \mathrm{h}^{-1}$. The moisture balance measured ventilation rate varied from $3231 \mathrm{~m}^{3} \cdot \mathrm{h}^{-1}$ to $11498 \mathrm{~m}^{3} \cdot \mathrm{h}^{-1}$ and the heat balance measured ventilation rate changed between $2705 \mathrm{~m}^{3} \cdot \mathrm{h}^{-1}$ and $10242 \mathrm{~m}^{3} \cdot \mathrm{h}^{-1}$ (Table 2 ). The operational status and rotational speed of ventilation fans were monitored at six stages. The minimum and maximum ventilation rates occurred in 00:00-5:00 and 11:00-14:00, respectively. The average moisture and heat balance ventilation rate of pig barn was $6207 \mathrm{~m}^{3} \cdot \mathrm{h}^{-1}, 5880 \mathrm{~m}^{3} \cdot \mathrm{h}^{-1}$, and the difference of ventilation rate between directly measured and balance measured during the field experiment was $137 \mathrm{~m}^{3} \cdot \mathrm{h}^{-1}, 189 \mathrm{~m}^{3} \cdot \mathrm{h}^{-1}$, respectively. However, small differentiations existed between the three methods, presumably resulting from the dynamic nature of the environmental conditions and pigs activities.

Table 2, Ventilation rate for pig building in different stage

\begin{tabular}{cccc}
\hline Time & Moisture balance & Sensible heat balance & Direct measurement \\
\hline 0:00-5:00 & $3231 \pm 531$ & $2705 \pm 511$ & $3100 \pm \mathrm{NA}$ \\
5:00-9:00 & $4540 \pm 544$ & $4387 \pm 1348$ & $4608 \pm \mathrm{NA}$ \\
9:00-11:00 & $8750 \pm 1130$ & $8677 \pm 1156$ & $8832 \pm \mathrm{NA}$ \\
11:00-14:00 & $11498 \pm 776$ & $10242 \pm 186$ & $11520 \pm \mathrm{NA}$ \\
14:00-17:00 & $9456 \pm 330$ & $9732 \pm 531$ & $9216 \pm \mathrm{NA}$ \\
$17: 00-0: 00$ & $4983 \pm 1001$ & $4685 \pm 1170$ & $4608 \pm \mathrm{NA}$ \\
\hline
\end{tabular}

\section{Conclusion}

The directly measured ventilation rate of a pig barn was $6069 \mathrm{~m}^{3} \cdot \mathrm{h}^{-1}$. The average moisture and heat balance ventilation rate of pig barn was $6207 \mathrm{~m}^{3} \cdot \mathrm{h}^{-1}, 5880 \mathrm{~m}^{3} \cdot \mathrm{h}^{-1}$, and the difference of ventilation rate between directly measured and balance measured during the field experiment was 137 $\mathrm{m}^{3} \cdot \mathrm{h}^{-1}, 189 \mathrm{~m}^{3} \cdot \mathrm{h}^{-1}$. For mechanical-ventilated growing pig house using manure gutters with daily manure removal, balance based on pig metabolic rate can be used to determine house ventilation rate with good result.

\section{Acknowledgements}

Funding was provided by Jiangsu Agriculture Science and Technology Innovation Fund (JASTIF) [CX (14)5074], Science and Technology Agency of Jiangsu Province (BE2014342-1) and Natural Science Foundation of Jiangsu Province (BK20170614). We sincerely appreciate the cooperation and assistance of the pig producer in the implementation of this field study. The authors would like to thank all farmers who participated in this study.

\section{References}

[1]. Samer M, Ammon C, Loebsin C, et al. Moisture balance and tracer gas technique for ventilation rates measurement and greenhouse gases and ammonia emissions quantification in naturally ventilated buildings. Building and Environment. Vol. 50(2012) No. 4, p. 10-20.

[2]. Place S E, Mitloehner F M. The nexus of environmental quality and livestock welfare. Annual Review of Animal Biosciences. Vol. 2(2014), p. 555-569.

[3]. Samer M, Loebsin C, Fiedler M, et al. Heat balance and tracer gas technique for airflow rates measurement and Gaseous emissions quantification in naturally ventilated livestock buildings. Energy and Buildings. Vol. 43(2011) No. 12, p. 3718-3728.

[4]. Ni J, Liu S, Lopes I, et al. Monitoring, modeling, and characterizing single-speed ventilation fans for an animal building. Building and Environment. Vol. 118 (2017) No. 3, p.225-233. 
[5]. Lin X, Cortus E, Zhang R,et al. Ventilation and Environmental Monitoring of Broiler Houses in California. Transactions of the ASABE. Vol. 54(2011) No. 3, p. 1059-1068.

[6]. Xin H, Li H, Gates R, et al. Use of $\mathrm{CO} 2$ concentration difference or $\mathrm{CO} 2$ balance to assess ventilation rate of broiler houses. Transactions of the ASABE. Vol. 52(2009) No. 4, p. 1353-1361.

[7]. Ogink N W M, Mosquera J, Calvet S, et al. Methods for measuring gas emissions from naturally ventilated livestock buildings: Developments over the last decade and perspectives for improvement. Biosystems Engineering. Vol. 116(2013) No. 3, p.297-308

[8]. Simmons, J. D., T. E. Hannigan, and B. D. Lott. A portable anemometer to determine the output of large in - place ventilation fans. Applied Eng. in Agric. Vol. 14(1998) No. 6, p. 649 - 653.

[9]. Gates R S, Casey K D, Xin H, et al. Fan assessment numeration system (FANS) design and calibration specifications. Transactions of the ASAE. Vol. 47(2004) No. 4, p. 1709-1715.

[10]. Calvet S, Cambra-López M, Blanes-Vidal V, et al. Ventilation rates in mechanically-ventilated commercial poultry buildings in Southern Europe: Measurement system development and uncertainty analysis. Biosystems Engineering. Vol. 106(2010) No. 6, p. 423-432.

[11]. Demmers T G M, Burgess L R, Phillips V R, et al. Assessment of techniques for measuring the ventilation rate, using an experimental building section. Journal of Agricultural Engineering Research. Vol. 76(2000), p. 71-81.

[12]. Demmers T G M, Phillips V R, Short L S, et al. Validation of ventilation rate measurement methods and the ammonia emission from naturally ventilated dairy and beef buildings in the United Kingdom. Journal of Agricultural Engineering Research. Vol. 79(2001) No. 1, p. 107-116.

[13]. Van Duinkerken G, Smits M C J, Andre ', G, et al. Milk urea concentration as an indicator of ammonia emission from dairy cow barn under restricted grazing. Journal of Dairy Science. Vol. 94(2011), p. 321-335.

[14]. Samer M, Fiedler M, Müller H J M, et al. developing the $85 \mathrm{Kr}$ tracer gas technique for air exchange rate measurements in naturally ventilated animal buildings, Biosystems Engineering. Vol. 109 (2011) No. 4, p. 276-287.

[15]. Samer M, Berg W, Müller H J, et al. Radioactive 85Kr and CO2 -balance for ventilation rate measurements and gaseous emissions quantification through naturally ventilated barns, Transactions of the ASABE. Vol. 54 (2011) No. 3, p. 1137-1148.

[16]. Van Buggenhout S, Van Brecht A, Eren Özcan S, et al. Influence of sampling positions on accuracy of tracer gas measurements in ventilated spaces. Biosystems Engineering. Vol. 104(2009) No. 8, p. 216-223.

[17]. Blanes V, Pedersen S. Ventilation Flow in Pig Houses measured and calculated by Carbon Dioxide, Moisture and Heat Balance Equations. Vol. 92 (2005), No. 4, p. 483-493.

[18]. Pedersen S; Takai H; Johnsen J O, et al. A comparison of three balance methods for calculating ventilation rates in livestock buildings. J. agric. Engng Res. Vol. 70(1998), No. 10, p. 25-37.

[19]. Schauberger G, Piringer M, Petz E. Steady-state balance model to calculate the indoor climate of livestock buildings, demonstrated for finishing pigs. Vol. 43 (2000), No. 4, p. 154-162. 